\title{
Metabolic Activity in the Visceral and Subcutaneous Adipose Tissues by FDG-PET/CT in Obese Patients
}

\author{
Avaliação da Atividade Metabólica do Tecido Adiposo \\ Visceral e Subcutâneo por FDG-PET/CT em Doentes \\ Obesos
}

Ana Margarida MONTEIRO $\rrbracket^{1}$, Gonçalo FERREIRA², Hugo DUARTE 2

Acta Med Port 2017 Nov;30(11):813-817 • https://doi.org/10.20344/amp.8712

\begin{abstract}
Introduction: The emerging role of the ${ }^{18} \mathrm{~F}$-fluorodeoxyglucose-positron emission tomography/computed tomography in the study of the metabolic activity and inflammation in adipose tissue indicates that it might be a reliable tool to complement the risk stratification in obesity. The aims of this study were the evaluation of ${ }^{18} \mathrm{~F}$-fluorodeoxyglucose uptake by visceral adipose tissues and subcutaneous adipose tissues and to determine eventual differences in patients with and without obesity.

Material and Methods: Retrospective study of adult patients who underwent whole body ${ }^{18} \mathrm{~F}$-fluorodeoxyglucose-positron emission tomography/ computed tomography scanning between July and August of 2016. Statistical analysis: SPSS ${ }^{\mathrm{TM}}$ software $^{\mathrm{v} .20}$. Statistical significance: $p<0.05$.

Results: We assessed fluorodeoxyglucose-positron emission tomography/computed tomography scans from 156 patients (58.3\% of males) with a mean age of $61.0 \pm 14.1$ years. Half of the patients had a body mass index $\geq 25.0 \mathrm{~kg} / \mathrm{m}^{2}$ and $15.4 \%(\mathrm{n}=24)$ were obese. In both groups, the mean ${ }^{18} \mathrm{~F}$-fluorodeoxyglucose uptake was higher in visceral adipose tissues. There were no differences in ${ }^{18} \mathrm{~F}$-fluorodeoxyglucose uptake in visceral adipose tissues between the groups. Obese patients had lower density of adipose tissue, both in subcutaneous adipose tissues and in visceral adipose tissues. Abdominal circumference and density of visceral adipose tissues had a positive predictive value in the mean ${ }^{18} \mathrm{~F}$-fluorodeoxyglucose uptake in visceral adipose tissues.

Discussion: Through a non-invasive test, this study demonstrated a significant higher metabolic activity in visceral adipose tissues in both obese and non-obese patients. According to our results, abdominal circumference was an important determinant in ${ }^{18} \mathrm{~F}$-fluorodeoxyglucose uptake in visceral adipose tissues. We also demonstrated that obese patients had differences in adipose tissue quality. Conclusion: Our findings reinforce the importance of the adipose tissue quality and distribution for metabolic risk stratification. Keywords: Adipose Tissue/diagnostic imaging; Fluorodeoxyglucose F18; Intra-Abdominal Fat/diagnostic imaging; Obesity/diagnostic imaging; Positron-Emission Tomography; Subcutaneous Fat/diagnostic imaging
\end{abstract}

\section{RESUMO}

Introdução: $\mathrm{O}^{18} \mathrm{~F}$-fluorodesoxiglucose-tomografia por emissão de pósitrons/tomografia computorizada tem sido aplicado ao estudo da atividade metabólica e da inflamação do tecido adiposo, constituindo uma possível ferramenta para complementar a estratificação de risco na obesidade. Os objetivos deste estudo foram a avaliação da captação de ${ }^{18} \mathrm{~F}$-fluorodesoxiglucose pelo tecido adiposo visceral e pelo tecido adiposo subcutâneo e a determinação de eventuais diferenças em doentes com e sem obesidade.

Material e Métodos: Estudo retrospetivo de doentes adultos submetidos a ${ }^{18} \mathrm{~F}$-fluorodesoxiglucose-tomografia por emissão de pósitrons/tomografia computorizada entre julho e agosto de 2016. Análise estatística: software SPSS ${ }^{\text {TM }}$ versão 20. Significância estatística: $p<0,05$.

Resultados: Foram avaliados os exames ${ }^{18} \mathrm{~F}$-fluorodesoxiglucose-tomografia por emissão de pósitrons/tomografia computorizada de 156 doentes (58,3\% eram homens) com idade média de 61,0 $\pm 14,1$ anos. Metade dos doentes apresentava índice de massa corporal $\geq 25,0 \mathrm{~kg} / \mathrm{m}^{2}$ e $15,4 \%(n=24)$ eram obesos. Em ambos os grupos, a captação média de ${ }^{18} \mathrm{~F}$-fluorodesoxiglucose foi superior no tecido adiposo visceral. Não houve diferenças na captação de ${ }^{18} \mathrm{~F}$-fluorodesoxiglucose no tecido adiposo visceral entre os grupos. Os doentes obesos apresentaram menor densidade do tecido adiposo, quer no tecido adiposo visceral como no tecido adiposo subcutâneo. A circunferência abdominal e a densidade do tecido adiposo visceral tiveram um valor preditivo positivo na captação média de ${ }^{18} \mathrm{~F}$-fluorodesoxiglucose no tecido adiposo visceral.

Discussão: Através de um exame não invasivo, demonstrou-se a existência de atividade metabólica significativamente maior no tecido adiposo visceral, comparativamente ao tecido adiposo subcutâneo, em doentes com e sem obesidade. De acordo com os nossos resultados, a circunferência abdominal foi um determinante importante na captação de ${ }^{18} \mathrm{~F}$-fluorodesoxiglucose no tecido adiposo visceral. Demonstramos ainda que os doentes obesos apresentaram diferenças na qualidade do tecido adiposo.

Conclusão: Os nossos resultados reforçam a importância da qualidade e da distribuição do tecido adiposo para a estratificação do risco metabólico.

Palavras-chave: 18F-Fluorodesoxiglucose; Gordura Intra-Abdominal/diagnóstico por imagem; Gordura Subcutânea/diagnóstico por imagem; Obesidade/diagnóstico por imagem; Tecido Adiposo/diagnóstico por imagem; Tomografia por Emissão de Pósitrons

\section{INTRODUCTION}

Adipose tissue is an active endocrine organ with a central role in lipid and glucose metabolism. It produces a large number of hormones and cytokines involved in the development of metabolic syndrome, diabetes mellitus and vascular diseases. ${ }^{1}$ The overall adiposity excess is associated with cardiovascular morbidity and mortality but

1. Serviço de Endocrinologia. Hospital de Braga. Braga. Portugal.

2. Serviço de Medicina Nuclear. Instituto Português de Oncologia do Porto. Porto. Portugal.

$\square$ Autor correspondente: Ana Margarida Monteiro. anamargaridacmonteiro@gmail.com

Recebido: 21 de janeiro de 2017 - Aceite: 30 de agosto de 2017 | Copyright @ Ordem dos Médicos 2017 
the different distribution of fat depots is associated with differential metabolic risk. It is well established that increased visceral adipose tissue (VAT) is strongly correlated with an adverse metabolic risk profile. By contrast, the increased subcutaneous adipose tissue (SAT) seems to have less importance on adverse risk profile. ${ }^{2-4}$

The differences between VAT and SAT concerning secretion of inflammatory mediators, gene expression and cell morphology have already been documented. Recently, ${ }^{18} \mathrm{~F}$-fluorodeoxyglucose (FDG)-positron emission tomography (PET) combined with computed tomography (CT) imaging has been used for the study of glucose metabolic activity and inflammation in adipose tissue. It has been demonstrated that metabolic activity in the VAT and SAT might be differentially regulated and FDG$\mathrm{PET} / \mathrm{CT}$ imaging could be a reliable tool for evaluating this parameter and to complement the cardiometabolic risk calculation. 5,6

The aims of this study were the evaluation of the uptake of FDG by VAT and SAT and to determine differences in patients with and without obesity who underwent whole body ${ }^{18}$ FDG-PET/CT scanning for clinical purposes (cancer diagnosis or staging).

\section{MATERIALS AND METHODS \\ Subjects and protocol}

We retrospectively analyzed 156 consecutive adult patients who underwent whole body ${ }^{18} \mathrm{FDG}-\mathrm{PET} / \mathrm{CT}$ scanning for clinical purposes (diagnosis or staging of cancer) between July and August of 2016.

Information regarding diabetes (medical history of diabetes and/or medication), hypertension and dyslipidemia was obtained from medical records.

Weight and height were self-reported and thereafter BMI (body mass index) was calculated. Obesity was considered in patients with a BMI greater than $30 \mathrm{~kg} / \mathrm{m}^{2}$. Abdominal circumference from cross-sectional CT image was measured using the software recommended by the National Institutes of Health - ImageJ. ${ }^{7}$

After fasting for six hours, the patients received FDG intravenously (if blood glucose was $\leq 250 \mathrm{mg} / \mathrm{dL}$ ). Whole body images were acquired on a PET/CT scanner (Siemens

Table 1 - Characteristics of the study population $(n=156)$

\begin{tabular}{lc}
\hline Variables & Results \\
\hline Age (years) (mean \pm SD) & $61.0 \pm 14.1$ \\
Gender (female // male) (\%) & $41.7 / / 58.3$ \\
Diabetes (\%) & 14.7 \\
Hypertension (\%) & 42.3 \\
Dyslipidemia (\%) & 34.0 \\
Obesity (\%) (BMI $\left.\geq 30 \mathrm{~kg} / \mathrm{m}^{2}\right)$ & 15.4 \\
Overweight $(\%)\left(25 \mathrm{~kg} / \mathrm{m}^{2} \leq \mathrm{BMl}<30 \mathrm{~kg} / \mathrm{m}^{2}\right)$ & 34.6 \\
BMI $\left(\mathrm{kg} / \mathrm{m}^{2}\right)(\mathrm{mean} \pm \mathrm{SD})$ & $25.6 \pm 4.6$ \\
Abdominal circumference $(\mathrm{cm})(\mathrm{mean} \pm \mathrm{SD})$ & $97.4 \pm 11.2$ \\
Fasting glucose $(\mathrm{mg} / \mathrm{dL})(\mathrm{median} ; \mathrm{IQR})$ & $104.0 ; 96.0-116.0$ \\
\hline
\end{tabular}

SD: Standard deviation; IQR: Interquartile range; BMI: Body mass index

Biograph 6) 50 to 90 minutes after tracer administration. Low-dose, non-contrast CT scan was performed for attenuation correction and anatomical localization. PET scan was acquired in 3-dimensional mode from base of skull to mid-thigh. Siemens Syngo MI Applications VA60A software was used for image analysis.

Regions of interest (ROIs) in VAT (epiploon), SAT (L3 level), liver (right hepatic lobe), psoas muscle and myocardium were drawn and the intensity of FDG uptake (maximum and mean SUV) was analyzed in these locations. Also, to determine the density of VAT and SAT, the Hounsfield units (HU) were recorded.

\section{Statistical analysis}

Normal distribution of the variables was evaluated through histogram. Continuous variables were expressed as mean and standard deviation or as median and interquartile range (IQR). Categorical variables were expressed as frequencies and percentages. Group comparisons were made using the $t$ test or Mann-Whitney $U$ test for continuous variables and the chi-square $\left(\chi^{2}\right)$ test for categorical variables. Linear regression analysis was performed to identify independent parameters associated with the mean FDG uptake in VAT and SAT. Statistical significance was defined at $p<0.05$. All statistical analysis was performed using SPSS ${ }^{\mathrm{TM}}$ software version 20 .

\section{RESULTS}

The mean age of the 156 patients was $61.0 \pm 14.1$ years and there was a predominance of males $(n=91 ; 58.3 \%)$. Half of the patients $(n=78 ; 50 \%)$ were overweight [body mass index $(\mathrm{BMI}) \geq 25.0 \mathrm{~kg} / \mathrm{m}^{2}$ ] and $15.4 \%$ ( $\left.n=24\right)$ were considered obese $\left(\mathrm{BMI} \geq 30 \mathrm{~kg} / \mathrm{m}^{2}\right)$. The detailed clinical characteristics of the study population are presented in Table 1.

The study population was divided in two groups (obese and non-obese) with similar age and gender distribution. Differences in clinical characteristics and FDG uptake values between the groups are represented in Table 2 .

The mean FDG uptake was higher in VAT than in SAT in both groups ( 0.5 vs $0.26 ; p<0.001$ and 0.6 vs $0.28 ; p<$ 0.001 , obese and non-obese patients respectively). 
Table 2 - Differences in clinical characteristics and FDG uptake values between groups

\begin{tabular}{|c|c|c|c|c|}
\hline Variables & $\begin{array}{l}\text { Obesity } \\
(n=24)\end{array}$ & $\begin{array}{l}\text { Without obesity } \\
\qquad(n=132)\end{array}$ & $\begin{array}{c}\text { Total } \\
(n=156)\end{array}$ & $p$ value \\
\hline Age (years) (mean \pm SD) & $65.8 \pm 10.2$ & $60.1 \pm 14.6$ & $61.0 \pm 14.1$ & $0.07^{\circ}$ \\
\hline Female gender (\%) & 54.2 & 39.4 & 41.7 & $0.2^{*}$ \\
\hline $\mathrm{BMI}\left(\mathrm{kg} / \mathrm{m}^{2}\right)($ mean $\pm \mathrm{SD})$ & $33.7 \pm 2.7$ & $24.1 \pm 3.1$ & $25.6 \pm 4.6$ & $<0.001^{\circ}$ \\
\hline Diabetes mellitus (\%) & 16.7 & 13.6 & 15.4 & $0.7^{*}$ \\
\hline Abdominal circumference $(\mathrm{cm})($ mean $\pm S D)$ & $112.6 \pm 9.0$ & $94.6 \pm 9.2$ & $97.4 \pm 11.2$ & $<0.001^{\circ}$ \\
\hline Fasting glucose (mg/dL) (median; IQR) & $102.0 ; 22.0$ & $104.5 ; 19.0$ & $104.0 ; 20.0$ & $0.6+$ \\
\hline VAT maximum FDG uptake (median; IQR) & $1.4 ; 0.8$ & $1.25 ; 0.6$ & $1.28 ; 0.6$ & $0.2 \dagger$ \\
\hline VAT mean FDG uptake (median; IQR) & $0.5 ; 0.3$ & $0.6 ; 0.3$ & $0.6 ; 0.3$ & $0.4 \dagger$ \\
\hline VAT density (HU) (median; IQR) & $-101.9 ; 7.7$ & $-93.4 ; 20.2$ & $-96.5 ; 18.7$ & $<0.001 \dagger$ \\
\hline SAT maximum FDG uptake (median; IQR) & $0.7 ; 0.3$ & $0.6 ; 0.3$ & $0.6 ; 0.3$ & $0.03+$ \\
\hline SAT mean FDG uptake (median; IQR) & $0.26 ; 0.09$ & $0.28 ; 0.2$ & $0.26 ; 0.2$ & $0.008+$ \\
\hline SAT density (HU) (median; IQR) & $-111.5 ; 11.0$ & $-106.5 ; 18.0$ & $-107.5 ; 15.0$ & $0.008+$ \\
\hline Muscle mean FDG uptake (median; IQR) & $0.9 ; 0.2$ & $0.7 ; 0.2$ & $0.7 ; 0.2$ & $<0.001 \dagger$ \\
\hline Liver mean FDG uptake (median; IQR) & $2.4 ; 0.4$ & $2.1 ; 0.7$ & $2.2 ; 0.6$ & $0.001 \dagger$ \\
\hline Myocardium maximum FDG uptake (median; IQR) & $4.3 ; 3.2$ & $5.1 ; 4.8$ & $5.1 ; 4.7$ & $0.6 \dagger$ \\
\hline
\end{tabular}

SD: Standard deviation; BMI: Body mass index; IQR: Interquartile range; VAT: Visceral adipose tissue; SAT: Subcutaneous adipose tissue; FDG: ${ }^{18}$ F-fluorodeoxyglucose; HU: Hounsfield units; ${ }^{\circ} t$-test; $†$ Mann-Whitney $\cup$ test; ${ }^{*}$ Chi-square tests

There were no differences in FDG uptake in VAT (mean and maximum SUV) between the groups.

Obese patients had higher maximum FDG uptake $(0.7$ vs $0.6 ; p=0.02$ ) but lower mean FDG uptake (0.26 vs 0.28 ; $p=0.008)$ in SAT. Also, this group had higher FDG uptake in liver (2.4 vs $2.1 ; p=0.001)$ and in muscle $(0.9$ vs $0.7 ; p<$ $0.001)$.

We observed lower density, determined by HU, of VAT $(-101.9$ vs $-93.4 ; p<0.001)$ and SAT $(-111.5$ vs $-106.5 ; p=$ $0.008)$ in obese patients.

Table 3 and 5 shows the coefficients of correlation (Spearman correlation) between the mean uptake in VAT and in SAT, respectively, and the different studied variables. Subsequently, a multiple linear regression analysis was performed to identify independent parameters associated with the mean FDG uptake in VAT $[F(4,151)=632.95$, $\left.p<0.001, R^{2}=0.942\right]$ and SAT $[F(8,147)=14.373, p$ $<0.001, R^{2}=0.439$ ] (Tables 4 and 6 , respectively). We found that the abdominal circumference and the density of VAT had a positive predictive value in the mean FDG uptake in VAT. In SAT, higher BMI and maximum uptake in myocardium were independent and negatively associated with the mean FDG uptake. Density of SAT and VAT and mean uptake in muscle had a positive predictive value in the mean uptake in SAT.

\section{DISCUSSION}

Our study demonstrated a higher FDG uptake in VAT, comparatively to SAT, in both obese and non-obese patients. Similar findings were reported by other authors, and it is assumed to be correlated to a higher metabolic activity in VAT. Furthermore, this difference could reflect the different profile of inflammatory mediators secreted between the two adipose tissues, supporting the concept that VAT is more strongly correlated with adverse metabolic profile risk. ${ }^{5,8-11}$

Notwithstanding the known link between obesity and inflammation, there were no differences in FDG uptake in VAT between patients with or without obesity. This result is in conformity with Christen et al, but in contrast with the results of Oliveira et al, where obese patients had higher FDG uptake in VAT. 5,10

We found a positive and independent association between abdominal circumference and mean FDG uptake in VAT. However, BMI was not associated with the mean FDG uptake in VAT. Those observations support the fact that adipose tissue distribution might have a more important role than excess adiposity per se in metabolic risk stratification. ${ }^{12}$

In concordance with Rosenquist et al, obese patients had lower density of VAT and SAT. It is known that the lower density is a marker of a more lipid dense and less vascularity of fat tissue. Rosenquist et al have also found that a lower CT attenuation (measured in HU) in VAT and in SAT was correlated with higher BMI. Moreover, the lower density of VAT and SAT was associated with a more adverse cardiometabolic risk. ${ }^{13}$ Besides, our regression analysis demonstrated that density in VAT and in SAT were independent and positively associated with uptakes in VAT and in SAT, supporting the concept that higher density is associated with higher metabolic activity.

Remarkably, obese patients had higher maximum FDG uptake but lower mean FDG uptake in SAT. Also, in the regression analysis, higher BMI was independently associated with lower mean FDG uptake in SAT. As higher $\mathrm{BMI}$ is associated with lower density of adipose tissue, the lower density in obese patients could explain the lowering effect in the mean FDG uptake.

Similar to the study of Oliveira et al, we observed higher 
Table 3 - Spearman correlations between mean uptake in VAT and the studied variables

\begin{tabular}{lcc}
\hline Variables & \multicolumn{2}{c}{ FDG uptake in VAT (mean) } \\
\hline Age & $r$ & 0.76 \\
Glycaemia & -0.024 & 0.79 \\
BMI & 0.021 & 0.054 \\
Abdominal circumference & -0.154 & 0.049 \\
VAT density & -0.158 & $<0.001$ \\
SAT mean FDG uptake & 0.487 & $<0.001$ \\
SAT density & 0.450 & 0.001 \\
Muscle mean FDG uptake & 0.266 & 0.146 \\
Liver mean FDG uptake & 0.117 & 0.961 \\
Myocardium maximum FDG uptake & -0.004 & 0.148 \\
\hline
\end{tabular}

VAT: Visceral adipose tissue; FDG: ${ }^{18} \mathrm{~F}$-fluorodeoxyglucose; BMI: Body mass index; SAT: Subcutaneous adipose tissue

Table 4 - Linear regression analyses for the significant correlation of FDG uptake in VAT

\begin{tabular}{|c|c|c|c|}
\hline \multirow[b]{2}{*}{ Variables } & & FDG uptake in VAT (mean) & \\
\hline & B & $\mathrm{t}$ & $p$ \\
\hline Abdominal circumference & 0.445 & 2.939 & 0.004 \\
\hline VAT density & 0.885 & 49.344 & $<0.001$ \\
\hline SAT density & -0.183 & -1.814 & 0.072 \\
\hline SAT mean FDG uptake & -24.844 & -1.975 & 0.05 \\
\hline
\end{tabular}

VAT: Visceral adipose tissue; FDG: ${ }^{18} \mathrm{~F}$-fluorodeoxyglucose; SAT: Subcutaneous adipose tissue

Table 5 - Spearman correlations between mean uptake in SAT and the studied variables

\begin{tabular}{|c|c|c|}
\hline \multirow[b]{2}{*}{ Variables } & \multicolumn{2}{|c|}{ FDG uptake in SAT (mean) } \\
\hline & r & $p$ \\
\hline Age & 0.305 & $<0.001$ \\
\hline Glycaemia & 0.198 & 0.013 \\
\hline $\mathrm{BMI}$ & -0.242 & 0.002 \\
\hline Abdominal circumference & -0.137 & 0.089 \\
\hline SAT density & 0.478 & $<0.001$ \\
\hline VAT mean FDG uptake & 0.450 & $<0.001$ \\
\hline VAT density & 0.316 & $<0.001$ \\
\hline Muscle mean FDG uptake & 0.207 & 0.009 \\
\hline Liver mean FDG uptake & 0.106 & 0.189 \\
\hline Myocardium maximum FDG uptake & -0.203 & 0.011 \\
\hline
\end{tabular}

SAT: Subcutaneous adipose tissue; FDG: ${ }^{18} \mathrm{~F}$-fluorodeoxyglucose; BMI: Body mass index; VAT: Visceral adipose tissue

Table 6 - Linear regression analyses for correlates of metabolic activity in SAT

\begin{tabular}{|c|c|c|c|}
\hline \multirow[b]{2}{*}{ Variables } & \multicolumn{3}{|c|}{ FDG uptake in SAT (mean) } \\
\hline & B & $\mathrm{t}$ & $p$ \\
\hline Age & 0.001 & 1.899 & 0.06 \\
\hline Glycaemia & 0.00067 & 0.273 & 0.785 \\
\hline $\mathrm{BMI}$ & -0.006 & -2.185 & 0.030 \\
\hline SAT density & 0.003 & 5.488 & $<0.001$ \\
\hline VAT mean FDG uptake & -0.001 & -1.839 & 0.068 \\
\hline VAT density & 0.001 & 2.104 & 0.037 \\
\hline Muscle mean FDG uptake & 0.179 & 3.526 & 0.001 \\
\hline Myocardium maximum FDG uptake & -0.005 & -2.310 & 0.022 \\
\hline
\end{tabular}

SAT: Subcutaneous adipose tissue; FDG: ${ }^{18} \mathrm{~F}$-fluorodeoxyglucose; BMI: Body mass index; VAT: Visceral adipose tissue 
FDG uptake in muscle of obese patients. ${ }^{10}$ Although the muscle FDG uptake can increase with hyperglycemia, there were no differences in glycemia between the groups. So, further examinations under steady-state conditions with dynamic PET are warranted to determine the glucose flux.

Obese patients had higher FDG uptake in liver and this is consistent with the results of the study of Batallés et al. In that study, liver FDG uptake was independently associated with BMI, age and gender. ${ }^{14}$ The higher FDG uptake in the liver might be a consequence of a chronic inflammatory response, probably steatosis. In our population, further correlation with CT attenuation could answer that question. Nevertheless, chemotherapy agents and concomitant liver disease were not evaluated and these variables are known to influence the FDG uptake.

Interestingly, the mean uptake in VAT was not correlated with uptake in other tissues such as muscle and myocardium. However, SAT mean uptake was independently associated with a lower myocardium uptake and a higher muscle uptake. Those findings may correspond to a different pattern of regulation, but further studies are needed to confirm that hypothesis.

Our retrospective study had some limitations to note.

An important limitation was the fact that our study population was not comprised of healthy subjects, as they underwent ${ }^{18} \mathrm{FDG}-\mathrm{PET} / \mathrm{CT}$ scanning for cancer diagnosis or staging. Also, the ongoing treatments and cancer staging were not controlled.

Another limitation was the FDG uptake measure in SUV. It is known that SUV can have inter and intra subject variability as a result of multiple factors, including glycemia, insulin concentrations and the time of image acquisition after FDG injection.

We lacked adipose tissue quantification that could help with better correlation and explanation of our findings.

Finally, this was a retrospective study and we lacked the fasting lipid profile, insulin levels and indices of inflammation that could complement the study.

\section{CONCLUSION}

A non-invasive ${ }^{18} \mathrm{FDG}-\mathrm{PET} / \mathrm{CT}$ scanning allowed us to demonstrate significant differences between SAT and VAT metabolic activity in both obese and non-obese patients.

According to our results, abdominal circumference is an important determinant in FDG uptake in VAT. We also demonstrated that obese patients had lower density which is a marker of a lipid-laden fat tissue and minor vascularity. Our findings reinforce the importance of the adipose tissue quality and distribution for metabolic risk stratification.

\section{PROTECTION OF HUMANS AND ANIMALS}

The authors declare that the procedures were followed according to the regulations established by the Clinical Research and Ethics Committee and to the Helsinki Declaration of the World Medical Association.

\section{DATA CONFIDENTIALITY}

The authors declare having followed the protocols in use at their working center regarding patients' data publication. Informed consent was duly obtained from the patient.

\section{CONFLICTS OF INTEREST}

All authors report no conflict of interest.

\section{FUNDING SOURCES}

This research received no specific grant from any funding agency in the public, commercial, or not-for-profit sectors.

\section{REFERENCES}

1. Haas B, Schlinkert P, Mayer P, Eckstein N. Targeting adipose tissue. Diabetol Metab Syndr. 2012;4:43.

2. Abraham TM, Pedley A, Massaro JM, Hoffmann U, Fox CS. Association between visceral and subcutaneous adipose depots and incident cardiovascular disease risk factors. Circulation. 2015;132:1639-47.

3. Liu J, Fox CS, Hickson DA, May WD, Hairston KG, Carr JJ, et al. Impact of abdominal visceral and subcutaneous adipose tissue on cardiometabolic risk factors: The Jackson Heart Study. J Clin Endocrinol Metab. 2010;95:5419-26.

4. Fox CS, Massaro JM, Hoffmann U, Pou KM, Maurovich-Horvat P, Liu CY, et al. Abdominal visceral and subcutaneous adipose tissue compartments: Association with metabolic risk factors in the framingham heart study. Circulation. 2007;116:39-48.

5. Christen T, Sheikine Y, Rocha VZ, Hurwitz S, Goldfine AB, Di Carli $M$, et al. Increased glucose uptake in visceral versus subcutaneous adipose tissue revealed by PET imaging. JACC Cardiovasc Imaging. 2010;3:843-51.

6. Tahara N, Yamagishi SI, Kodama N, Tahara A, Honda A, Nitta Y, et al. Clinical and biochemical factors associated with area and metabolic activity in the visceral and subcutaneous adipose tissues by FDG-PET/ CT. J Clin Endocrinol Metab. 2015;100:E739-47.

7. Gomez-Perez SL, Haus JM, Sheean P, Patel B, Mar W, Chaudhry V, et al. Measuring abdominal circumference and skeletal muscle from a single cross-sectional computed tomography image: A step-by-step guide for clinicians using National Institutes of Health Image J. JPEN J

Parenter Enteral Nutr. 2015;3:308-18.

8. Virtanen KA, Lönnroth P, Parkkola R, Peltoniemi P, Asola M, Viljanen $T$, et al. Glucose uptake and perfusion in subcutaneous and visceral adipose tissue during insulin stimulation in nonobese and obese humans. J Clin Endocrinol Metab. 2002;87:3902-10.

9. Virtanen KA, lozzo P, Ha K, Huupponen R, Parkkola R, Janatuinen T, et al. Increased fat mass Ccompensates for insulin resistance in abdominal obesity and type 2 diabetes. Outlook. 2005;54.

10. Oliveira AL, Azevedo DC, Bredella MA, Stanley TL, Torriani M. Visceral and subcutaneous adipose tissue FDG uptake by PET/CT in metabolically healthy obese subjects. Obesity. 2015;23:286-9.

11. Ng JM, Azuma K, Kelley C, Pencek R, Radikova Z, Laymon C, et al. PET imaging reveals distinctive roles for different regional adipose tissue depots in systemic glucose metabolism in nonobese humans. Am J Physiol Endocrinol Metab. 2012;303:E1134-41.

12. Després JP. Body fat distribution and risk of cardiovascular disease: An update. Circulation. 2012;126:1301-13.

13. Rosenquist KJ, Pedley A, Massaro JM, Therkelsen KE, Murabito JM, Hoffmann $U$, et al. Visceral and subcutaneous fat quality is associated with cardiometabolic risk. Int J Cardiovasc Imaging. 2013;6:762-71.

14. Batallés SM, Villavicencio RL, Quaranta A, Burgos L, Trezzo S, Staffieri $\mathrm{R}$, et al. Variaciones del SUV hepático con relación al índice de masa corporal en estudios PET/TC de cuerpo entero. Rev Esp Med Nucl Imagen Mol. 2013;32:26-32. 